\title{
Consumption of energy drinks and assessment of blood pressure values among young adults
}

\author{
JULIA MARTYNA-G, ZDZISŁAWA CHMIEL ${ }^{A, c, F}$ \\ Institute of Health Sciences, Medical College of Rzeszow University, Poland
}

A - Study Design, B - Data Collection, C - Statistical Analysis, D - Data Interpretation, E - Manuscript Preparation, F - Literature Search, G - Funds Collection

Summary Background. The consumption of energy drinks is increasing, and there are more and more diseases caused by their abuse. Objectives. The aim of the study is to check the relationship between the characteristics of consumption of energy drinks by young adults and the occurrence of high blood pressure in the study group.

Material and methods. The diagnostic survey method, estimation method and measurement were used in the research's implementation. The author's questionnaire was used as a tool. As part of the measurements, three measurements of blood pressure in basic conditions were made. A total of 309 students from two high school schools in Rzeszow took part in the study.

Results. Systolic hypertension amounted to $14.9 \%$ and diastolic $18.8 \%$ of the students. After consumption of energy drinks, it reached $45.3 \%$ of the students surveyed. People who drank energy drinks more often had higher systolic $(56.5 \%)$ and diastolic hypertension $(44.8 \%)$ values than in those who did not drink then $(p<0.001)$. Respondents who drank $3-4$ cans $(17.4 \%)$ and those who drank 5 or more energy drinks $(10.9 \%)$ most often had systolic hypertension $(p<0.001$, Kendall's tau $=0.39)$. There is a dependence between the level of intensiveness of consumption of energy drinks and the values of arterial blood pressure $(p<0.05)$.

Conclusions. Energy drinks were consumed by almost half of the students tested. The study of the relationship between the characteristics of energy drink consumption and the distribution of the blood pressure values of the studied group shows that the frequency, number and period of consumption of energy drinks have a significant impact on the distribution of blood pressure.

Key words: blood pressure, energy drinks, hypertension, young adults.

Martyn J, Chmiel Z. Consumption of energy drinks and assessment of blood pressure values among young adults. Fam Med Prim Care Rev 2019; 21(4): 335-342, doi: https://doi.org/10.5114/fmpcr.2019.90162.

\section{Background}

High blood pressure values are more and more often recognised in young adults [1]. Hypertensive disease occurs in about $7.2 \%$ of adolescents [2]. Obesity and overweight are considered as the main causes of primary hypertension in children. Too high blood pressure affects about $3-3.5 \%$ of the population under the age of 18 . In recent years, the epidemiology of primary hypertension has increased [3]. One reasons for the high blood pressure values in young adults may be various types of stimulators, such as energy drinks [4]. Koziarska-Rościszewska and Wiśniewska in their research, showed that adult high school students (18-20 years old) often have improper dietary habits. Nearly $24 \%$ consumed "energy" drinks in the amount of 0.1-2.0 litres per week [5]. Long-term consumption of caffeine and other stimulants in energy drinks results in increased tension of the walls of blood vessels. As a result, there is hypertrophy of the muscle membrane and increased neuroendocrine stimulation. This situation causes a disturbance of the balance between vasoconstrictor and vasodilator substances. Such disorders may be the main cause of hypertension, but they are also the cause of primary disorders associated with increased cardiac output. Because of the continuous consumption of energy drinks containing caffeine or other stimulants, which maintain high pressure in the walls of blood vessels, accelerated destruction of elastin occurs. This protein is replaced with collagen, which increases the stiffness of the vascular wall. This leads to loading of the left ventricle, its hypertrophy and secondary myocardial ischemia, leading to degenerative changes [6].

According to the information on the packaging, energy drinks are intended mainly for healthy adults who can drink them from time to time in emergency situations [7]. However, the most common group of people consuming energy drinks are young people aged 15 to 25 , the so-called "core consumer", i.e. students and young, intensively working residents of large cities (25-35 years) - "metro consumer" [8].

We can find many substances in the composition of energy drinks. The main elements are substances that stimulate the central nervous system and improve concentration and reduce fatigue. Energy drinks are not a source of energy, as there are few substances that provide energy in their composition. Energy drinks provide only $2-3 \%$ of the daily calories. Their task is not to provide energy, only psychophysical stimulation. Caffeine, taurine and glucose are usually added to energy drinks [9].

Caffeine in beverages is a synthetic product that is absorbed faster than the natural one contained in coffee. Therefore, the obtained effect of stimulation of the body is short-lived. The level of caffeine drops quickly, and the body becomes tired. This results in reaching for a further dose of caffeine [10]. It is dangerous to consume several cans of energy drinks a day [11]. The accumulation of caffeine in the blood of a person and the long-term consumption of other stimulants cause an increase in the tension of the walls of blood vessels, which contributes to the formation of hypertension $[12,13]$. Seifert has published a study that shows that long-term elevated blood pressure can cause hypertension and arrhythmia in the future. Therefore, children and adolescents should not consume energy drinks [8].

Energy drinks are often confused with isotonic. Isotonic drinks contain less sugar and do not contain addictive substances. They include water, mineral salts and electrolytes. The lack of knowledge about energy drinks and isotonic beverages probably leads to confusion of these drinks, resulting in harm to health [14]. 
It is important to identify the risk factors and early symptoms of cardiovascular diseases at the earliest stage. The presence of certain pathologies is conducive to people leading a worse lifestyle than healthy people. Patients treated for cardiovascular events are less physically active, have worse dietary habits and are more likely than healthy individuals to have addictions [15].

\section{Objectives}

The aim of the work was to check the relationship between the characteristics of energy drinks consumed by young adults and the occurrence of high blood pressure values in the studied group, both in the scope of systolic and diastolic components.

\section{Material and methods}

\section{Study design}

The diagnostic survey method, estimation method and measurement were used in the research's implementation. Among the research techniques, the survey technique was used, using an original questionnaire which consisted of 19 questions. The questions were focused on health behaviours regarding the consumption of energy drinks. In the questionnaire, students declared whether they consume energy drinks or do not drink these beverages. Students were also asked about the frequency of consumption of energy drinks and the amount of energy drinks consumed and the period of consumption of energy drinks. In the questionnaire, students were asked an open question about the type of energy drinks consumed most often. The questionnaire was also designed to check whether students regularly measured blood pressure. Students were also asked about the knowledge of the value of their arterial blood pressure.

\section{Setting}

The permission of the directors of the branches was obtained for conducting the tests. The research plan was strictly consulted with the management and staff of the facility. Each respondent was familiar with the information about the study. After reading the information, the respondents provided written permission to take part in the study. The study was approved by the Ethics Committee of the University of Rzeszow (27/04/2016).

As part of the measurements, blood pressure measurements were performed 3 times in basic conditions at intervals of no more than 2 weeks. The auscultation method was used with the use of an aneroid sphygmomanometer and stethoscope. The sphygmomanometer was validated. The pressure gauge was periodically checked and had a certificate. The measurements were performed in a sitting position with the prevailing guidelines regarding the selection of the appropriate cuff and the measurement stages. The result of the measurement was read on the scale of the manometer, with an accuracy of $\pm 3 \mathrm{~mm}$ $\mathrm{Hg}$. The first measurement was made on both arms, while subsequent measurements were performed on the limb on which higher pressure values were found. The person examined did not eat, smoke, drink alcohol and take drugs 30 minutes earlier, which could affect the measurement result, and the person was not under stress. The respondents rested in a sitting position before the study.

\section{Participants}

The research consisted of 309 students. The selection of people for the study was random. The students' age was -18 years and 1 month to 20 years and 4 months (mean 18.46). In this group, there were more women $(62.8 \%, n=194)$ than men $(37.2 \%, n=115)$. The largest group of respondents were people living in rural areas $(51.8 \%, n=160) .58 .3 \%$ of the respondents attended science classes $(n=180)$, and $41.7 \%$ of the respondents attended liberal arts $(n=129)$. Most often, the respondents indicated that they had a good financial situation $(61.5 \%$, $n=190$ ).

\section{Bias}

In the questionnaire, no trade names of energy drinks were given. As a result, energy drinks were not advertised in the questionnaire. The respondents wrote the names of energy drinks they drank.

\section{Study size}

The size of the test group was calculated by the Calculator for the Size of the Test Sample. The respondents attended selected high school in the city of Rzeszow. The selection of schools was random. The study excluded pupils with pre-existing hypertension and subjects who were being treated for hypertension. Pupils with overweight and obesity were excluded from the study (Body Mass Index $\leq 25$ ).

\section{Quantitative variables}

The respondents declared in the questionnaire whether they drink energy drinks, how often they drink these drinks and what is the one-off amount of energy drinks consumed. Respondents were also asked about the period of consuming energy drinks. The group of drinks were also quantitative variables. In the questionnaire, students wrote the names of energy drinks they drink most often. Next, the research group divided the drinks listed by the students into four groups: A, B, C, D. The authors divided the beverages into groups and were guided by their composition. Group A contained only caffeine. Group B contained taurine. Group $C$ had caffeine and taurine in its composition. In contrast, group D contained only glucose.

\section{Statistical methods}

The mean was analysed in relation to general blood pressure values and in the scope of individual components, i.e. systolic and diastolic pressure. The obligatory norms of the European Society of Hypertension and the European Cardiac Society were used to interpret the obtained results [16]. Statistical analysis of the verification of differences between variables was carried out with the test 2 independence test, assuming a significance level of $p<0.05$. When the level of significance was $p<0.001$, the following tests were used to verify the hypotheses: Cramer's V, Phi. For questions on ordinal scales, Kendall's tau or chi-square test were used. The calculations were performed using IBM SPSS Statistics 20.

\section{Results}

Systolic hypertension amounted to $14.9 \%$ of the students and diastolic $18.8 \%$ of the students. Elevated pressures were more frequent in men than in women (Cramer's $\mathrm{V}=0.30, p<0.05$ ). Examining the extreme values of systolic blood pressure, it can be concluded that the maximum value of the systolic blood pressure measurement was $177 \mathrm{~mm} \mathrm{Hg}$, the minimum - $77 \mathrm{~mm}$ $\mathrm{Hg}$. However, the maximum value of the diastolic pressure measurement $-110 \mathrm{~mm} \mathrm{Hg}$, the minimum $-53 \mathrm{~mm} \mathrm{Hg}$.

After energy drinks, this reached $45.3 \%$ in the students surveyed. Men drank these beverages more often, in larger quantities and for a longer time than women $(p<0.05)$. Analysing the relationship between the declaration of consumption of energy drinks and values of blood pressure in the study group, it can be seen that in people who consume energy drinks more often, there was higher systolic (56.5\%) and diastolic hypertension (44.8\%) than in those who did not drink them. The respondents 


\begin{tabular}{|c|c|c|c|c|c|c|c|c|c|c|}
\hline & & & \multicolumn{3}{|c|}{ Systolic pressure } & \multirow{2}{*}{$\begin{array}{l}\text { Alto- } \\
\text { gether }\end{array}$} & \multicolumn{3}{|c|}{ Diastolic pressure } & \multirow{2}{*}{$\begin{array}{l}\text { Alto- } \\
\text { gether }\end{array}$} \\
\hline & & & correct & \begin{tabular}{|l} 
correct \\
high
\end{tabular} & $\begin{array}{l}\text { hyper- } \\
\text { tension }\end{array}$ & & correct & $\begin{array}{l}\text { correct } \\
\text { high }\end{array}$ & $\begin{array}{l}\text { hyper- } \\
\text { tension }\end{array}$ & \\
\hline \multirow{6}{*}{$\begin{array}{l}\text { Declaration of con- } \\
\text { sumption of energy } \\
\text { drinks }\end{array}$} & \multirow[t]{2}{*}{ I don't drink } & $n$ & 149 & 15 & 5 & 169 & 146 & 11 & 12 & 169 \\
\hline & & $\%$ & 70.3 & 29.4 & 10.9 & 54.7 & 72.3 & 22.4 & 20.7 & 54.7 \\
\hline & \multirow[t]{2}{*}{ often } & $n$ & 10 & 12 & 26 & 48 & 8 & 14 & 26 & 48 \\
\hline & & $\%$ & 4.7 & 23.5 & 56.5 & 15.5 & 4.0 & 28.6 & 44.8 & 15.5 \\
\hline & \multirow[t]{2}{*}{ occasionally } & $n$ & 53 & 24 & 15 & 92 & 48 & 24 & 20 & 92 \\
\hline & & $\%$ & 25.0 & 47.1 & 32.6 & 29.8 & 23.8 & 49.0 & 34.5 & 29.8 \\
\hline \multirow{2}{*}{\multicolumn{2}{|c|}{ Altogether }} & $n$ & 212 & 51 & 46 & 309 & 202 & 49 & 58 & 309 \\
\hline & & $\%$ & 100.0 & 100.0 & 100.0 & 100.0 & 100.0 & 100.0 & 100.0 & 100.0 \\
\hline & & & \multicolumn{4}{|c|}{$p<0.001$, Kendall's tau $=0.34$} & \multicolumn{4}{|c|}{$p<0.001$, Kendall's tau $=0.35$} \\
\hline \multirow[t]{10}{*}{ Frequency of drinking } & \multirow[t]{2}{*}{ I don't drink } & $n$ & 139 & 13 & 4 & 156 & 135 & 10 & 11 & 156 \\
\hline & & $\%$ & 65.6 & 25.5 & 8.7 & 50.5 & 66.8 & 20.4 & 19.0 & 50.5 \\
\hline & \multirow[t]{2}{*}{ every day } & $n$ & 0 & 4 & 14 & 18 & 1 & 6 & 11 & 18 \\
\hline & & $\%$ & 0 & 7.8 & 30.4 & 5.8 & 0.5 & 12.2 & 19.0 & 5.8 \\
\hline & \multirow{2}{*}{$\begin{array}{l}\text { a few times } \\
\text { a week }\end{array}$} & $n$ & 8 & 10 & 15 & 33 & 8 & 13 & 12 & 33 \\
\hline & & $\%$ & 3.8 & 19.6 & 32.6 & 10.7 & 4.0 & 26.5 & 20.7 & 10.7 \\
\hline & \multirow{2}{*}{$\begin{array}{l}\text { sev- } \\
\text { eral times } \\
\text { a month } \\
\end{array}$} & $n$ & 20 & 15 & 10 & 45 & 20 & 12 & 13 & 45 \\
\hline & & $\%$ & 9.4 & 29.4 & 21.7 & 14.6 & 9.9 & 24.5 & 22.4 & 14.6 \\
\hline & \multirow{2}{*}{$\begin{array}{l}\text { less than } \\
\text { once } \\
\text { a month }\end{array}$} & $n$ & 45 & 9 & 3 & 57 & 38 & 8 & 11 & 57 \\
\hline & & $\%$ & 21.2 & 17.6 & 6.5 & 18.4 & 18.8 & 16.3 & 19.0 & 18.4 \\
\hline \multirow{2}{*}{\multicolumn{2}{|c|}{ Altogether }} & $n$ & 212 & 51 & 46 & 309 & 202 & 49 & 58 & 309 \\
\hline & & $\%$ & 100.0 & 100.0 & 100.0 & 100.0 & 100.0 & 100.0 & 100.0 & 100.0 \\
\hline & & & \multicolumn{4}{|c|}{$p<0.001$, Kendall's tau $=0.19$} & $p<0.00$ & , Kendall & tau $=0.2$ & \\
\hline Number of drinks & I don't drink & $n$ & 145 & 15 & 5 & 165 & 142 & 11 & 12 & 165 \\
\hline & & $\%$ & 68.4 & 29.4 & 10.9 & 53.4 & 70.3 & 22.4 & 20.7 & 53.4 \\
\hline & $\max .1$ & $n$ & 39 & 16 & 6 & 61 & 36 & 12 & 13 & 61 \\
\hline & & $\%$ & 18.4 & 31.4 & 13.0 & 19.7 & 17.8 & 24.5 & 22.4 & 19.7 \\
\hline & 1 to 2 & $n$ & 20 & 15 & 22 & 57 & 18 & 15 & 24 & 57 \\
\hline & & $\%$ & 9.4 & 29.4 & 47.8 & 18.4 & 8.9 & 30.6 & \begin{tabular}{|l|}
41.4 \\
\end{tabular} & 18.4 \\
\hline & 3 to 4 & $n$ & 5 & 4 & 8 & 17 & 3 & 7 & 7 & 17 \\
\hline & & $\%$ & 2.4 & 7.8 & 17.4 & 5.5 & 1.5 & 14.3 & 12.1 & 5.5 \\
\hline & 5 or more & $n$ & 3 & 1 & 5 & 9 & 3 & 4 & 2 & 9 \\
\hline & & $\%$ & 1.4 & 2.0 & 10.9 & 2.9 & 1.5 & 8.2 & 3.4 & 2.9 \\
\hline Altogether & & $n$ & 212 & 51 & 46 & 309 & 202 & 49 & 58 & 309 \\
\hline & & $\%$ & 100.0 & 100.0 & 100.0 & 100.0 & 100.0 & 100.0 & 100.0 & 100.0 \\
\hline & & & $p<0.00$ & , Kendall & $\operatorname{tau}=0.3$ & & $p<0.00$ & , Kendall & tau $=0.3$ & \\
\hline Period of drinking & I do not & $n$ & 150 & 15 & 5 & 170 & 147 & 11 & 12 & 170 \\
\hline & $\begin{array}{l}\text { drink energy } \\
\text { drinks }\end{array}$ & $\%$ & 70.8 & 29.4 & 10.9 & 55.0 & 72.8 & 22.4 & 20.7 & 55.0 \\
\hline & less than & $n$ & 9 & 4 & 3 & 16 & 9 & 4 & 3 & 16 \\
\hline & a year & $\%$ & 4.2 & 7.8 & 6.5 & 5.2 & 4.5 & 8.2 & 5.2 & 5.2 \\
\hline & 1 to 2 years & $n$ & 20 & 10 & 9 & 39 & 19 & 10 & 10 & 39 \\
\hline & & $\%$ & 9.4 & 19.6 & 19.6 & 12.6 & 9.4 & 20.4 & 17.2 & 12.6 \\
\hline & 3 to 4 years & $n$ & 21 & 13 & 11 & 45 & 17 & 10 & 18 & 45 \\
\hline & & $\%$ & 9.9 & 25.5 & 23.9 & 14.6 & 8.4 & 20.4 & 31.0 & 14.6 \\
\hline & 5 years or & $n$ & 12 & 9 & 18 & 39 & 10 & 14 & 15 & 39 \\
\hline & more & $\%$ & 5.7 & 17.6 & 39.1 & 12.6 & 5.0 & 28.6 & 25.9 & 12.6 \\
\hline Altogether & & $n$ & 212 & 51 & 46 & 309 & 202 & 49 & 58 & 309 \\
\hline & & $\%$ & 100.0 & 100.0 & 100.0 & 100.0 & 100.0 & 100.0 & 100.0 & 100.0 \\
\hline & & & $p<0.00$ & , Kendall' & $\operatorname{tau}=0.3$ & & $p<0.00$ & , Kendall & tau $=0.3$ & \\
\hline
\end{tabular}


consuming energy drinks occasionally mostly characterised by correct high in both systolic and diastolic component $(47.1 \%$ vs 49.0\%) (Table 1).

Analysing the relationship between the characteristics of consumption of energy drinks and the distribution of blood pressure values, it can be noticed that in people who consume energy drinks every day more often showed signs of systolic and diastolic hypertension than in people who did not consume these drinks (30.4\% vs. $19.0 \%$ ). Normal blood pressure values appeared only in people who did not consume energy drinks at all or who drank them less often than once a month. Respondents who drank 3-4 cans (17.4\%) and those who drank 5 or more cans $(10.9 \%)$ most often had systolic hypertension. In the scope of the diastolic component in the above-mentioned groups, normal high pressure was more often observed. The period of consumption of energy drinks also affected high blood pressure. Young people who consumed energy drinks for 5 years or more often had higher systolic hypertension (39.1\%) than those who drank these drinks for a shorter time (Table 1).

The study group was divided into 3 categories. The division was made on the basis of questions in the questionnaire regarding the frequency of consumption, the number of drinks and the period of drinking. In each of the questions, more frequent use of energy drinks was assigned a higher point value. The maximum number of points to be obtained was 18 , which was divided into 3 parts: low level - from 1 to 6 points, medium level - from 7 to 12 points, high level - from 13 to 18 points. People consuming energy drinks rarely, in small quantities, for a short period of time or not at all were classified into a low level of intake intensity. People who declared consumption of drinks on an occasional basis in medium quantity and for some time were qualified to the medium level. Students who drank energy drinks often and in large quantities were qualified to a high level (Figure 1).

Hypertension was more common among students with high levels (20.1\%), less frequent in subjects with medium levels $(6.8 \%)$ and least frequent in students with low levels (1.9\%). There is a dependence between the level of intensiveness of consumption of energy drinks and the values of arterial blood pressure $(p<0.05)$ (Figure 1$)$.

Energy drinks were divided into six groups based on their composition. This resulted in group $A$ or $A+D$, which is a single dose of caffeine in an energy drink. Group $A+C$ or $A+C+D$ means a double dose of caffeine and a single dose of taurine. Group $B$ or $B+D$ is a single dose of taurine. Group $B+C$ or $B+C$ $+D$ is a double dose of taurine. Group $A+B+C$ or $A+B+C+D$ is a double dose of caffeine and a double dose of taurine. Group $D$ is an energy drink that contains only glucose. The ratio of dependence showed a moderate statistical relationship between the classification of the blood pressure value and the group of energy drinks which contained a single dose of caffeine (Cramer's $\mathrm{V}=0.37, p<0.001$ ) and the group of drinks containing a single dose of taurine (Cramer's $V=0.32, p<0.001$ ). Students who consumed group A or A + D more often had hypertension (44.1\%) than those who did not drink this group (15.7\%). Respondents consuming group $B$ and $B+D$ more often had hypertension $(41.8 \%)$ than non-drinkers of this group (18.3\%) (Table 2).
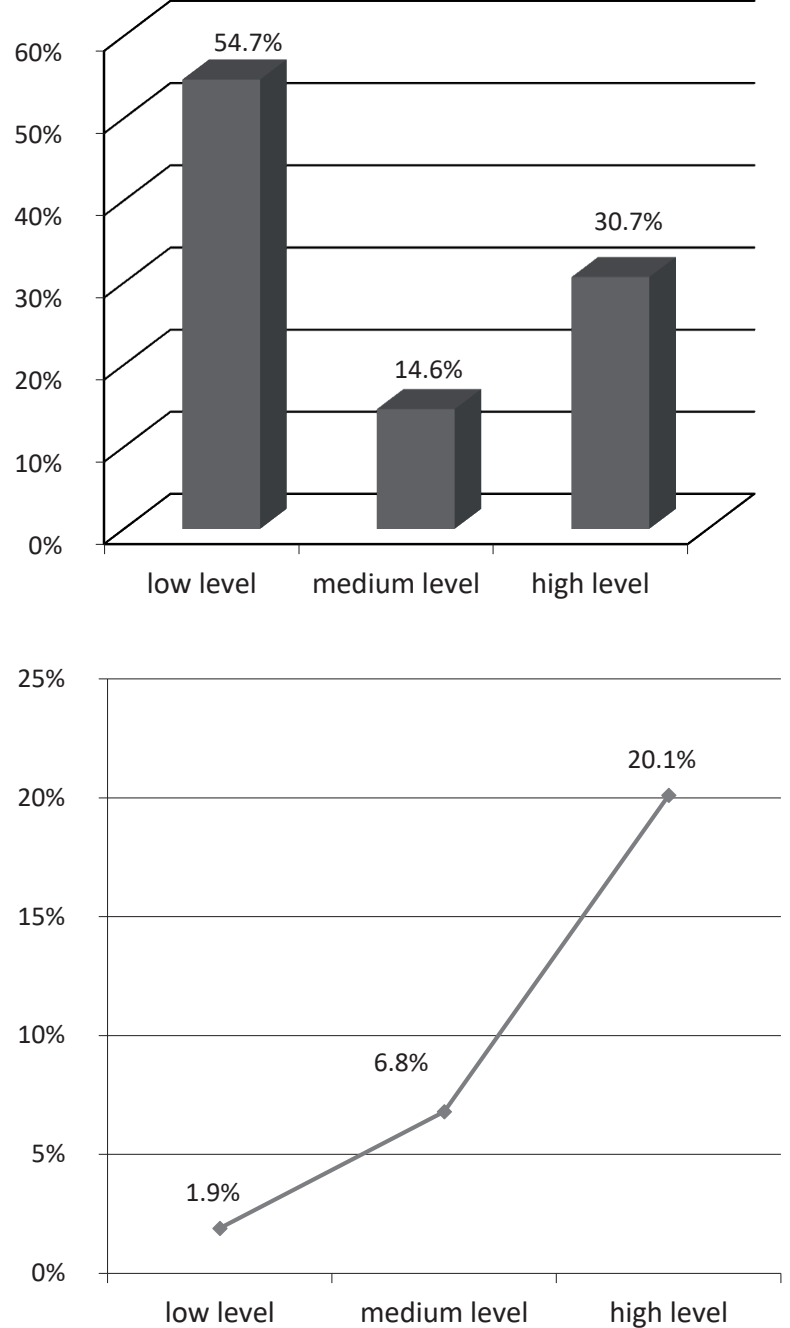

intensity level of consumption of energy drinks

Figure 1. Intensity level of consumption of energy drinks and dependence of the intensity level of consumption of energy drinks and hypertension 


\begin{tabular}{|c|c|c|c|c|c|c|}
\hline & & & \multicolumn{3}{|c|}{ Blood pressure } & \multirow[t]{2}{*}{ Altogether } \\
\hline & & & correct & correct high & hypertension & \\
\hline \multirow[t]{4}{*}{ Group A or A + D } & \multirow[t]{2}{*}{ drink } & $n$ & 30 & 22 & 41 & 93 \\
\hline & & $\%$ & 32.3 & 23.7 & 44.1 & 100 \\
\hline & \multirow[t]{2}{*}{ not drink } & $n$ & 152 & 30 & 34 & 216 \\
\hline & & $\%$ & 70.4 & 13.9 & 15.7 & 100 \\
\hline \multirow{2}{*}{\multicolumn{2}{|c|}{ Altogether }} & $n$ & 182 & 52 & 75 & 309 \\
\hline & & $\%$ & 58.9 & 16.8 & 24.3 & 100 \\
\hline \multicolumn{7}{|c|}{$p<0.001$, Cramer's V $=0.37$, chi-square test $=41.24$} \\
\hline \multirow[t]{4}{*}{ Group $A+C$ or $A+C+D$} & \multirow[t]{2}{*}{ drink } & $n$ & 40 & 33 & 61 & 134 \\
\hline & & $\%$ & 29.8 & 24.6 & 45.5 & 100 \\
\hline & \multirow[t]{2}{*}{ not drink } & $n$ & 142 & 19 & 14 & 175 \\
\hline & & $\%$ & 81.1 & 10.9 & 8 & 100 \\
\hline \multirow{2}{*}{\multicolumn{2}{|c|}{ Altogether }} & $n$ & 182 & 52 & 75 & 309 \\
\hline & & $\%$ & 58.9 & 16.8 & 24.3 & 100 \\
\hline \multicolumn{7}{|c|}{$p<0.001$, Cramer's V $=0.53$, chi-square test $=87.46$} \\
\hline \multirow[t]{4}{*}{ Group B or B + D } & \multirow[t]{2}{*}{ drink } & $n$ & 26 & 20 & 33 & 79 \\
\hline & & $\%$ & 32.9 & 25.3 & 41.8 & 100 \\
\hline & \multirow[t]{2}{*}{ not drink } & $n$ & 156 & 32 & 42 & 230 \\
\hline & & $\%$ & 67.8 & 13.9 & 18.3 & 100 \\
\hline \multirow{2}{*}{\multicolumn{2}{|c|}{ Altogether }} & $n$ & 182 & 52 & 75 & 309 \\
\hline & & $\%$ & 58.9 & 16.8 & 24.3 & 100 \\
\hline \multicolumn{7}{|c|}{$p<0.001$, Cramer's V $=0.32$, chi-square test $=31.05$} \\
\hline \multirow[t]{4}{*}{ Group B + Cor B + C+D } & \multirow[t]{2}{*}{ drink } & $n$ & 41 & 33 & 58 & 132 \\
\hline & & $\%$ & 31.1 & 25 & 43.9 & 100 \\
\hline & \multirow[t]{2}{*}{ not drink } & $n$ & 141 & 19 & 17 & 177 \\
\hline & & $\%$ & 79.6 & 10.7 & 9.6 & 100 \\
\hline \multirow{2}{*}{\multicolumn{2}{|c|}{ Altogether }} & $n$ & 182 & 52 & 75 & 309 \\
\hline & & $\%$ & 58.9 & 16.8 & 24.3 & 100 \\
\hline \multicolumn{7}{|c|}{$p<0.001$, Cramer's V $=0.51$, chi-square test $=80.43$} \\
\hline \multirow[t]{4}{*}{ Group A+B + C + D } & \multirow[t]{2}{*}{ drink } & $n$ & 45 & 35 & 62 & 142 \\
\hline & & $\%$ & 31.7 & 24.6 & 43.7 & 100 \\
\hline & not drink & $n$ & 137 & 17 & 13 & 167 \\
\hline & & $\%$ & 82 & 10.2 & 7.8 & 100 \\
\hline Altogether & & $n$ & 182 & 52 & 75 & 309 \\
\hline & & $\%$ & 58.9 & 16.8 & 24.3 & 100 \\
\hline$p<0.001$, Cramer's V $=0$ & i-square tes & & & & & \\
\hline Group D & drink & $n$ & 17 & 14 & 19 & 50 \\
\hline & & $\%$ & 34 & 28 & 38 & 100 \\
\hline & not drink & $n$ & 165 & 38 & 56 & 259 \\
\hline & & $\%$ & 63.7 & 14.7 & 21.6 & 100 \\
\hline Altogether & & $n$ & 182 & 52 & 75 & 309 \\
\hline & & $\%$ & 58.9 & 16.8 & 24.3 & 100 \\
\hline
\end{tabular}

$n$ - number of respondents; \% - the percentage of the respondent's group; $p$ - statistical significance coefficient.

There is a strong statistical relationship between the classification of blood pressure and the group of beverages containing a double dose of caffeine and a single dose of taurine (Cramer's V $=0.53, p<0.001$ ) $; \mathrm{B}+\mathrm{C}$ or $\mathrm{B}+\mathrm{C}+\mathrm{D}$ group of energy drinks (a double dose of taurine and a single dose of caffeine) - Cramer's V = 0.51, $p<0.001 ;$ and group $A+B+C+D(A+B$ $+C+D)-$ Cramer's $V=0.53, p<0.001$. Students consuming group $\mathrm{A}+\mathrm{C}$ or $\mathrm{A}+\mathrm{C}+\mathrm{D}$ more often had hypertension $(45.5 \%)$ than those who did not drink this group (8\%). The group of people who consumed the $\mathrm{B}+\mathrm{C}$ or $\mathrm{B}+\mathrm{C}+\mathrm{D}$ group of drinks more often developed hypertension (43.9\%) than those who did not drink this group (9.6\%). Students who reported consuming drinks with a double dose of caffeine and a double dose of taurine were more likely to have high blood pressure than students who did not drink this group. The ratio of dependence showed a weak statistical relationship between the classification of the blood pressure value and the group of energy drinks containing glucose alone (Cramer's V $=0.22$ ) (Table 2 ). 


\section{Discussion}

Scientific research shows that many people suffer from hypertensive disease [17]. A long-term study was carried out which shows that as many as 19\% of people aged $24-34$ had arterial blood pressure above $140 / 90 \mathrm{~mm} \mathrm{Hg}$ [18]. The most common cause of hypertension in children is obesity. Many studies have confirmed the effect of obesity on the increased occurrence of hypertension in children and adolescents [19]. In the present study, $24.3 \%$ of the students tested had hypertension. This is a disconcerting finding that suggests a continuous upward trend in the incidence of hypertension in an increasingly younger population [20]. Among many environmental factors affecting the development of hypertension, the consumption of energy drinks is mentioned [21]. Improper dietary habits affect the health status of teenagers. Dietary habits are among the most important lifestyle elements [22]. World research shows the dependence of consuming energy drinks with the occurrence of high values of blood pressure. This is probably because of the high doses of caffeine and other stimulants that are added to energy drinks $[11,13]$. In addition to energy drinks, young people consume coffee. This causes an accumulation of caffeine in the body. Consuming energy drinks and coffee leads to individuals exceeding the daily norm of caffeine consumption [23]. This summation causes a rapid increase in blood pressure [24]. In his publication, Del Coso et al. assessed the effect of energy drinks on heart rate. They noticed that after an hour of drinking an energy drink containing $3 \mathrm{mg}$ of caffeine per kilogram of body weight, there was a rapid acceleration of the heart rate, which lasted up to 4 hours [25]. Our own study also showed that there is a relationship between the consumption of energy drinks and the values of blood pressure. The highest values of blood pressure occurred in students consuming this type of drink. Young adults who declared that they did not consume energy drinks had mostly normal blood pressure. Respondents declaring the consumption of energy drinks were occasionally characterised most often by the correct high blood pressure values in terms of both components. It can be assumed that in this group of people, hypertension will develop in the future. In the present study, it can be seen that the more energy drinks consumed by the subjects, the higher the blood pressure values observed. Szotowska et al. came to similar conclusions in their study aimed at checking the effect of a single dose of an energy drink on the blood pressure of young, healthy people. They were given 3 drinks which contained various doses of caffeine $(0 \mathrm{mg}, 120 \mathrm{mg}$, $360 \mathrm{mg}$.) After consuming a drink containing $360 \mathrm{mg}$ of caffeine, after 15 minutes, there was a visible increase in blood pressure in each subject [26]. Literature states that after prolonged use of energy drinks, the body adapts to high doses of caffeine and individuals no longer notice any symptoms after consuming such a drink. In order for a stimulating effect to appear, more and more doses of stimulants are needed [23]. This is a dangerous phenomenon that leads to addiction and the effects of caffeine withdrawal [27]. Steinke checked the values of blood pressure immediately after consumption of $500 \mathrm{ml}$ of energy drinks and after 7 days of daily intake of $500 \mathrm{ml}$ of these beverages. He showed that both single and repeated doses of energy drinks affect systolic and diastolic pressure and heart rate. After 7 days of regular consumption of these beverages, the systolic and diastolic pressure increased by $10 \mathrm{~mm} \mathrm{Hg}$ [28]. Our own study also showed that young people who had been consuming energy drinks for a longer time had higher blood pressure.

World research shows the dependence of consuming energy drinks with the occurrence of high values of blood pressure. This is probably because of the high doses of caffeine and other stimulants that are added to the energy drinks [29]. Young people do not read product labels. They do not notice the composition of the product and the amount of individual substances in the beverage's composition. Krasnowska and Salejda, in her research, presented that $53 \%$ of Poles read information on the products they choose. Therefore, it can be said that half of the
Polish population does not read the composition of the products [30]. The data obtained in our own study shows that young adults most often choose energy drinks which contain in their composition as many as 2 stimulants, both caffeine and taurine. Such a drink has a stronger stimulating effect. It is assumed that in addition to drinks, young people also consume coffee, causing the amount of caffeine in the body to accumulate beyond the recommended standard of daily consumption of caffeine. This caffeine accumulation has effect on blood pressure values, causing a rapid increase in its value. Regularly intake of high doses of caffeine may cause hypertension [31]. On the market, you can find energy drinks which, in their composition, have only caffeine, taurine, both these ingredients or only glucose. The more stimulants they contain, the more damage caused in the body [29]. Most students consumed drinks which, in their composition, contained a double dose of caffeine and a double dose of taurine. Analysing the impact of particular groups of energy drinks on systolic and diastolic blood pressure, it can be concluded that in each group of drinks, a higher number of students had elevated blood pressure. Only in the group of beverages containing glucose alone did the majority of students have normal and optimal blood pressure. This result suggests that energy drinks have a significant effect on blood pressure. Kennedy and Scholey came to a similar conclusion in her study, which investigated the effect of individual components of energy drinks on the cognitive functions of the body. She noticed a connection between stimulating ingredients, such as caffeine and taurine, with an increase in blood pressure and improved efficiency of the body. Her study also confirms the fact that energy drinks containing only glucose create a placebo effect in the body. Drinks of this group slightly improve intellectual performance, but they have no relation to blood pressure. However, in combination with substances that stimulate glucose, it has a positive effect on improving concentration and reducing mental fatigue [32].

\section{Limitations of the study}

The number of energy drinks consumed, the period of consuming energy drinks and the frequency of their drinking have been estimated by means of survey questions. Experimental measurements were not made. It is uncertain whether the respondents consumed beverages with the actual composition that they reported in the questionnaire. A serious factor limiting the study was the authenticity of the respondents' statements. In questionnaire studies, the truthfulness of the respondents is very important [33]. The study tried to exclude an emotional component that could inflate the measurement of blood pressure. However, the stress on the respondents may not have been fully eliminated.

\section{Conclusions}

1. Energetic drinks were consumed by almost half of the students tested. The study of the relationship between the characteristics of energy drink consumption and the distribution of the blood pressure values of the studied group shows that the frequency, number and period of consumption of energy drinks have a significant impact on the distribution of blood pressure.

2. The intensity of consumption of energy drinks has a significant impact on the overall classification of arterial blood pressure. Students with a high intake of energy drinks were more likely to have elevated pressures.

3. Young adults most often consume energy drinks containing a double dose of caffeine and taurine. Consumption of each of the analysed groups of energy drinks determines the more frequent occurrence of elevated blood pressure values.

4. The results of the conducted research may in the future contribute to taking targeted practical actions towards the prevention of hypertension, as well as limiting the consumption of energy drinks among young adults. 
Source of funding: This work was funded from the authors' own resources.

Conflicts of interest: The authors declare no conflicts of interest.

\section{References}

1. Lurbe $E$, Litwin $M$, Pall D, et al. Insights and implications of new blood pressure guidelines in children and adolescents. $J$ Hypertens 2018; 36(7): 1456-1459.

2. Schwandt $\mathrm{P}$, Scholze J, Bertsch T, et al. Blood pressure percentiles in 22,051 German children and adolescents: the pep family heart study. Am J Hypertens 2015; 28(5): 672-679.

3. Kaelber DC, Liu W, Rosset M, et al. Diagnosis and medication treatment of pediatric hypertension: a retrospective cohort study. Pediatrics 2016; 138: e20162195, doi: 10.1542/peds.2016-2195.

4. Babu KM, Church RJ, Lewander W. Energy drinks: the new eye-opener for adolescents. Clin Pediatr Emerg Med 2008; 9(1): 35-42.

5. Koziarska-Rościszewska M, Wiśniewska K. The relationship between diet and other elements of lifestyle and the health status of adult high school students. Fam Med Prim Care Rev 2017; 19(3): 230-234.

6. Mesas AE, Leon-Muñoz LM, Rodriguez-Artalejo F, et al. The effect of coffee on blood pressure and cardiovascular disease in hypertensive individuals: a systematic review and meta-analysis. Am J Clin Nutr 2011; 94(4): 1113-1126.

7. Bessada SMF, Alves RC, Oliveira MBPP. Caffeine-based food supplements and beverages: trends of consumption for performance purposes and safety concerns. Food Res Int 2018; 109: 310-319.

8. Seifert S.M. Health effects of energy drinks on children, adolescents and young adults. Pediatrics 2011; 127(3): 511-528.

9. Bilek M, Stawarczyk K, Pasternakiewicz A. Zawartość glukozy, fruktozy i sacharozy w wybranych napojach typu soft drink. Probl Hig Epidemiol 2014; 95: 438-444 (in Polish).

10. O'Brien MC. Caffeinated cocktails: get wired, get drunk, get injured. Acad Emerg Med 2008; 15: 453-460.

11. Leal WE, Jackson DB. Energy drinks and escalation in drug use severity: an emergent hazard to adolescent health. Prev Med 2018; 111: 391-396.

12. Giles GE, Mahoney CR, Brunye TT, et al. Differential cognitive effects of energy drink ingredients: caffeine, taurine, and glucose. Pharmacol Biochem Be 2012; 102(4): 569-577.

13. Mattioli AV, Pennella S, Farinetti A, et al. Energy drinks and atrial fibrillation in young adults. Clin Nutr 2018; 37(3): $1073-1074$.

14. Joachimiak I, Szołtysek K. Świadomość, stan wiedzy oraz częstotliwość spożycia napojów energetyzujących i izotonicznych przez osoby młode, czynnie uprawiające sport. Nauk Inż Technol 2013; 1: 26-38 (in Polish).

15. Muszyński J, Żółtańska J, Michalczak W, et al. Analiza stylu życia dorosłych mieszkańców Dolnego Śląska w aspekcie zapobiegania chorobom sercowo-naczyniowym. Fam Med Prim Care Rev 2016; 18(1): 33-38 (in Polish).

16. Williams B, Mancia G, Spiering W, et al. 2018 ESC/ESH Guidelines for the management of arterial hypertension. Eur Heart J 2018; 39(33): 3021-3104.

17. Miura K, Daviglus M, Dyer AR, et al. Relationship of blood pressure to 25-year mortality due to coronary heart disease, cardiovascular diseases, and all causes in young adult men: the Chicago Heart Association Detection Project in Industry. Arch Intern Med 2001; 161(12): 1501-1508.

18. Nguyen QC, Tabor JW, Entzel PP, et al. Discordance in national estimates of hypertension among young adults. Epidemiology 2001; 22(4): 532-541.

19. Pirogowicz I, Ornat M, Pachołek K, et al. Evaluation of fat mass and its correlation with abnormal blood pressure in children and adolescents. Fam Med Prim Care Rev 2017; 19(3): 256-260.

20. Jardim TV, Carneiro CS, Morais P, et al. White-coat, masked and sustained hypertension detected by home blood pressure monitoring in adolescents: prevalence and associated factors. Blood Press 2018; 27(3): 151-157.

21. Chrysant SG, Chrysant GS. Cardiovascular complications from consumption of high energy drinks: recent evidence. J Hum Hypertens 2015; 29(2): 71-76.

22. Koziarska-Rościszewska M, Wiśniewska K. The relationship between diet and other elements of lifestyle and the health status of adult high school students. Fam Med Prim Care Rev 2017; 19(3): 230-234.

23. Nowak D, Gośliński M, Nowatkowska K. The effect of acute consumption of energy drinks on blood pressure, heart rate and blood glucose in the group of young adults. Int J Environ Res Public Health 2018; 15(3): 544, doi: 10.3390/ijerph15030544.

24. Papaioannou TG, Karatzi K, Karatzis E, et al. Acute effects of caffeine on arterial stiffness, wave reflections, and central aortic pressures. Am J Hypertens 2005; 18(1): 129-136.

25. Del Coso J, Salinero J, Gonzalez-Millan C, et al. Dose response effects of a caffeine-containing energy drink on muscle performance: a repeated measures design. J Int Soc Sports Nutr 2012; 9(1): 21, doi: 10.1186/1550-2783-9-21.

26. Szotowska M, Bartmańska M, Wyskida K, et al. Wpływ jednorazowej dawki tak zwanego napoju energetyzującego na ciśnienie tętnicze i częstość tętna u młodych, zdrowych osób dorosłych. Arterial Hypertension 2013; 17(2): 169-174 (in Polish).

27. Scholey A, Kennedy D. Cognitive and physiological effects of an energy drink: an evaluation of the whole drink and of glucose, caffeine and herbal flavouring fractions. Psychopharmacology 2004; 176: 320-330.

28. Steinke L. Effect of "energy drink" consumption on hemodynamic and electrocardiographic parameters in health young adults. Ann Pharmacother 2009; 43: 596-602.

29. Curran CP, Marczinski CA. Taurine, caffeine, and energy drinks: reviewing the risks to the adolescent brain. Birth Defects Res 2017; 109: 1640-1648.

30. Krasnowska G, Salejda A. Ocena wiedzy konsumentów na temat znakowania żywności. Żywn Nauka Technol Jakość 2011; 74: 173-189 (in Polish).

31. Zulli A, Smith RM, Kubatka P, et al. Caffeine and cardiovascular diseases: critical review of current research. Eur J Nutr 2016; 55: 1331-1343.

32. Kennedy D, Scholey A. Cognitive and physiological effects of an „energy drink”: an evaluation of the whole drink and of glucose, caffeine and herbal flavouring fractions. Psychopharmacology 2004; 176: 320-330.

33. Bänziger T, Mortillaro M, Scherer K. Introducing the Geneva Multimodal Expression Corpus for experimental research on emotion perception. Emotion 2012; 12: 1161-1179.

Tables: 2

Figures: 1

References: 33 
Received: 17.03.2019

Reviewed: 14.04 .2019

Accepted: 30.06 .2019

Address for correspondence:

Julia Martyn, MSc

Instytut Nauk o Zdrowiu

Kolegium Nauk Medycznych

Uniwersytet Rzeszowski

al. mjr. W. Kopisto 2a

35-310 Rzeszów

Polska

Tel.: +48 17 872-11-09

E-mail: martyn1420@gmail.com 